DOI https://doi.org/10.18551/rjoas.2017-09.09

\title{
ANALYSIS OF DISTRIBUTION CHALLENGES ON FOREIGN TOURIST IN INDONESIA: A STUDY ON DKI JAKARTA
}

\author{
Yulianto Edy \\ Business Administration Department, Faculty of Administrative Science, \\ University of Brawijaya, Indonesia \\ E-mail: edy y fia@ub.ac.id
}

\begin{abstract}
Tourism industry is one of the available solutions in facing economic problems in Indonesia and is one source of foreign exchange. Tourism sector created foreign exchange up to US\$ 12.5 billion or equivalent to IDR 163 trillions in 2015. It is ranked 4th in Indonesia's foreign exchange earnings under other business lines, such as palm oil, coal, and natural gas. There are various entrances of foreign tourists to Indonesia. There are 3 (three) largest entrance to foreign tourists. Those are Bali, Jakarta Capital City Special Region (DKI Jakarta), and Batam. According to BPS in November 2016, the number of foreign tourists visiting Bali was 396,150 visits, DKI Jakarta 219,246 visits, and Batam 106,953 visits. The study aims to determine, describe and analyze the distribution channels of foreign tourists that occurred in DKI Jakarta, which gains the second largest number of foreign tourist arrival after Bali. This research was conducted to determine the reason behind DKI Jakarta ranks 2nd in Indonesia compared to other tourist cities in Indonesia.
\end{abstract}

\section{KEY WORDS}

Tourism, foreign tourist, foreign currency, tourist entrance.

Tourism is one of the new types of industries capable of accelerating economic growth, employment, income generation, living standards and stimulate other productive sectors. Traveling is a process of one leaving their residence to another location, which is conducted for at least 24 hours or more. The reasons for conducting tourism activities are economic, social, cultural, political, religious, health reasons or conducting study and gaining experience (Pendit, 2005: 32; Suwantoro, 2004: 3; Yoeti, 2003: 47).

Tourism industry has been included as a solution in facing economic problems in Indonesia. Economic problems caused by declining sectors, rising imports and slow development are deemed to be overcome by the tourism industry in Indonesia because the tourism industry can create jobs vacancy and gain foreign exchange for the country. The tourism industry is also a means to safeguard and encourage economic development. For Indonesia, tourism can enhance mutual respect and international tolerance (Suwantoro: 2004: 37).

Tourism is one source of foreign exchange. The tourism sector created foreign exchange up to US\$12.5 billion or equivalent to Rp163 trillion in 2015. It ranked 4th in Indonesia's foreign exchange earnings compared to other business lines, under palm oil, coal, and natural gas.

Table 1 describes Indonesian foreign exchange earnings and projection of foreign exchange earnings from the main sectors of the Indonesian economy taken from the Central Bureau of Statistics (BPS) and Pusat Data Informasi or Central Information Data (Pusdatin).

Table 1 exhibits foreign exchange earnings from tourism field in 2013 to 2015 which continue to increase. In contrast to other business fields that tend to decrease or unstabl. The projection charts made by Kemenpar exhibits foreign exchange earnings from tourism sector will rank first in comparison with other sectors by 2019 (Pusdatin, Kemenpar, 2014)

There are various entrances of foreign tourists to Indonesia. There are 3 (three) largest entrance to foreign tourists. Those are Bali, DKI Jakarta, and Batam. According to BPS, total visitors in Bali on November 2016 were 396,150. On the other hand, DKI Jakarta 219,246 visits and Batam 106,953 visits. However, there's a huge gap between the three cities and 
other cities in Indonesia. Most visitors other cities received was 20,000 in November 2016, which occurs in cities such as Medan and Surabaya. The condition exhibits a gap in the foreign tourist's distribution channel. Foreign tourist visits are concentrated in certain cities, especially DKI Jakarta, despite Indonesia possessing a number of a tourist destination. DKI Jakarta is included in 2 (two) major as the entrance of foreign tourists to Indonesia. DKI Jakarta is the capital city of the Republic of Indonesia which is also the only city in Indonesia which has a provincial level status with an area of $661.52 \mathrm{~km}^{2}$. DKI Jakarta as the capital of the Republic of Indonesia becomes the center of government, trade and economy activities.

The high number of foreign tourist arrivals to Jakarta every month compared to other cities exhibits a contrast inequality for tourism in Indonesia. Foreign tourists are focused on 3 (three) main destinations such as Bali, Jakarta, and Batam. Good distribution channels to foreign tourists are required in order to introduce Indonesia's tourism potential. For it has various tourist destinations not sought after by the majority of foreign tourists.

Table 1 - Indonesian Foreign Currency Earnings According to Business Field

\begin{tabular}{|c|c|c|c|c|c|c|}
\hline \multirow{2}{*}{ No. } & \multicolumn{2}{|c|}{2013} & \multicolumn{2}{c|}{2014} & \multicolumn{2}{c|}{2015} \\
\cline { 2 - 7 } & Commodity Type & $\begin{array}{c}\text { Value } \\
\text { (Billion US\$) }\end{array}$ & Commodity Type & $\begin{array}{c}\text { Value } \\
\text { (Billion US\$) }\end{array}$ & Commodity Type & $\begin{array}{c}\text { Value } \\
\text { (Billion US\$) }\end{array}$ \\
\hline 1 & Oil \& Gas & $32.633,2$ & Oil \& Gas & $30.318,8$ & Oil \& Gas & $18.906,7$ \\
\hline 2 & Coal & $24.501,4$ & Coal & $20.819,3$ & Coal & $16.359,6$ \\
\hline 3 & Palm Oil & $15.839,1$ & Palm Oil & $17.464,9$ & Palm Oil & $15.485,0$ \\
\hline 4 & Tourism & $10.0541,1$ & Tourism & $11.166,3$ & Tourism & $12.578,6$ \\
\hline 5 & $\begin{array}{c}\text { Processed } \\
\text { Rubber }\end{array}$ & $9.316,6$ & $\begin{array}{c}\text { Processed } \\
\text { Rubber }\end{array}$ & $7.450,9$ & $\begin{array}{c}\text { Processed } \\
\text { Rubber }\end{array}$ & $7.340,5$ \\
\hline 6 & Clothing & $7.501,0$ & Clothing & $7.021,7$ & Clothing & $6.351,2$ \\
\hline 7 & $\begin{array}{c}\text { Electric } \\
\text { Equipments }\end{array}$ & $6.418,6$ & $\begin{array}{c}\text { Electric } \\
\text { Equipments }\end{array}$ & $6.486,8$ & $\begin{array}{c}\text { Electric } \\
\text { Equipments }\end{array}$ & $5.997,4$ \\
\hline 8 & Processed Food & $5.434,8$ & Processed Food & $6.259,1$ & Processed Food & $5.713,3$ \\
\hline 9 & Textile & 5.293 .6 & Textile & $5.379,7$ & Textile & $5.048,8$ \\
\hline 10 & $\begin{array}{c}\text { Paper and paper } \\
\text { goods }\end{array}$ & $3.802,2$ & $\begin{array}{c}\text { Paper and paper } \\
\text { goods }\end{array}$ & $3.914,1$ & $\begin{array}{c}\text { Paper and paper } \\
\text { goods }\end{array}$ & $3.647,5$ \\
\hline
\end{tabular}

Source: BPS and Pusdatin Ministry of Tourism of Indonesia (Kemenpar), 2015.

\section{LITERATURE REVIEW}

Tjiptono and Chandra (2012: 393) "The program of distribution and sales can be defined as a program consisting of various marketing activities seeking to facilitate goods and services distribution from producers to consumers, to ensure usage is in accordance with requirement (type, quantity, price, place, and time required) ". Channel Members (Anggota Saluran) function according to Kotler and Keller's research (2008: 112) is to gather information about potential customers and current customers, competitors, and other actors and forces in marketing environment; develop and perform persuasive communication to encourage purchases; reaching price agreements and other terms so ownership transfer can be influenced; placing orders to producers; obtain funding to finance inventories at various levels within the marketing channel; assume risks associated with the implementation of channel work; provide storage and movement of physical products seamlessly; providing bills for buyer payments through banks and other financial institutions; overseeing the actual transfer of ownership from one organization or person to another organization or person. The marketing channel is not just limited to the distribution of physical goods. Services and ideas are a "product" which is invisible but possess benefits for humans and are consumed by humans in certain activities. The production may and may not be tied to a product.

Schulalard (in Yoeti, 1982: 105) provides a tourism limitation which is stated as the following: "Tourism is the sum of operations, mainly of an economic nature, which is directly related to the entry, stay and movement of the foreign inside a certain country, city or region". It indicates that tourism is a number of activities, especially economic ones, which are directly connected with entry, settling and transfer of foreigners in a certain country, city or region. 
Freuler (in Yoeti 1982: 105-106) defines the notion of tourism in the modern sense as a phenomenon of the present age based on health and atmosphere change need, conscious and cultivating (Citra) appreciation of nature's beauty in particular due to the increased people association and human society classes as a result of commerce, industry, trade and transportation refinement development. Hunzieker and Krapf (1942) as stated in Yoeti (1982: 106) described "Tourism is totally of the relationship and phenomena arising from the travel and stay strangers (Ortsfremde), provide the stay does not imply the establishment of a permanent resident".

The Tourism Committee of the Organization for Economic Cooperation and Development in 1970 provided restrictions on tourist definition. "A person becomes a tourist if he visits a place at least 24 hours; if for a shorter period, i.g. under 24 hours, he is counted as an excursionist ". Furthermore, for the benefit of marketing in tourism promotion, Schmoll (Yoeti, 1982: 127) provides the following limits: "Tourist: individuals or groups of individuals who, considering their purchasing power available for vacation and recreational travel, interest in and motivation for travel in general, past travel behaviour, existing knowledge, interest and awareness concerning the services or destinations concerned, are likely to prospects for a future visit".

According to Burkart and Medlik, in Ross (Ross, 1998: 4-5), tourists possess three main characteristics. These three features are:

- Tourists are people who travel to and live in various destinations;

- Tourist destinations are different from their respective origin and residence; as tourist activity differs from locals who live and work in tourist destinations;

- Tourists intend to return home after a few days or months; therefore the journey is temporary and short-term.

\section{METHODS OF RESEARCH}

This research is a qualitative research utilizing descriptive approach, as descriptive method describes an event obtained by researchers related to the distribution channel of foreign tourists in DKI Jakarta. Researchers used this type of qualitative research as an attempt to describe the events according to data and facts obtained through existing research in the field.

The research was conducted in DKI Jakarta, as it becomes the entry point for the 2nd largest foreign tourist after Bali. The research was undertaken in Department of Tourism DKI Jakarta, the distributor of foreign tourists (travel agent), Indo Citra Tamasya Travel Agent Company and foreign tourists. These sites were selected existing data and information which are accurate and relevant to analyze the distribution channel of foreign tourists centered in DKI Jakarta.

Primary data sources are data obtained directly from field research. The source is obtained from the relevant parties as informants in research object. Data obtained from the interviews result between researchers and related parties. In this case, the informants are:

- The Jakarta Tourism Office, the Head of Data \& Information Division;

- Party Travel Agent / Travel Agent ie, Finance Director Indo Citra Tamasya;

- Foreign tourists: Vojtech Bazant (Czech Republic), Kieran (England) and Naomi (England).

The secondary data source is data obtained indirectly from source, but collected by other party and secondary data in this research. Those secondary data are:

- Foreign tourist data entering DKI Jakarta;

- Data of foreign tourist visit to museum in DKI Jakarta.

\section{RESULTS AND DISCUSSION}

DKI Jakarta ranks 2nd in the number of foreign tourists arriving in Indonesia after Bali. Based on the results of interviews with the Jakarta Tourism Office, foreign tourists who come 
to DKI Jakarta mostly conduct MICE tourism (Meeting, Incentive, Convention, and Event). In addition to MICE tours, foreign tourists mostly shops. The statement was also reinforced and complemented by private parties or travel agents stating that a high number of foreign tourists visiting DKI Jakarta does not fully wish travel in DKI Jakarta region. Instead, they use it as a transit area before continuing to other areas in Indonesia. It exhibits foreign tourists visiting Jakarta joins a type of convention tour. According to the private sector in general, access to Indonesia is centralized in DKI Jakarta, because foreign airlines transit in DKI Jakarta, the cooperation of airlines affects the high number of foreign tourists who come to DKI Jakarta. The readiness of the region/city or airport is also reinforced by the result of the interview from the Jakarta Tourism Department which states that DKI Jakarta was ready sooner compared to other cities, therefore there is existing gap of foreign tourists entering DKI Jakarta.

The interview exhibits a high number of foreign tourists visiting Jakarta has a positive impact. The gap of total tourist compared to other cities is affected by the readiness of the region and the airport respectively. The impact of the phenomenon is also maintained by the government and the private sector in advancing DKI Jakarta economy. Based on interviews with foreign tourists Vojtech Bazant (Czech Republic) and Kieran Rieley (UK) from their perspective as tourists, they do not know the sights in DKI Jakarta. They commented on lack of tourism activity in Jakarta, the lack of maps for international tourists, lack of places to visit, a bustling city, very difficult mobility, therefore, causing difficulty in traversing the city and other places. Foreign tourists' comments on lack of Indonesian tourism promotion. European tourist stated that the government should optimise promotion on Indonesia. The Jakarta Tourism Department stated that the government has conducted promotional tips and the private sector follows the government's policy in relation to promoting Indonesian tourism. Private parties commented that the government's promotional policy never sells DKI Jakarta as a tourist destination and focuses on other regions in Indonesia. Indo Citra Tamasya believes that the high number of foreign tourists does not make DKI Jakarta as their final destination, but the condition of the airport and airline that requires them to come to Jakarta for transit plane then continue the trip to other destinations in Indonesia.

Foreign Tourist Distribution Channel. Based on distribution channel, DKI Jakarta ranks second in foreign tourist arrival. Jakarta Tourism Department stated that there is no special attention, system or strategy for the distribution channel of foreign tourists to DKI Jakarta. This is due to the readiness of DKI Jakarta airport which has cooperated with international airlines to channel tourists. DKI Jakarta Tourism Office focuses more on MICE tourism, due to the available infrastructure. Tourism products in DKI Jakarta cater to MICE tour, whereas tourism products in Bali focused on nature tourism. Tourism Department also explained that the imbalance is only a matter of access to other areas due to limited direct flight (direct flight).

The Jakarta Tourism Department stated that the inequality merely the fact that airlines lands in DKI Jakarta. Nevertheless, foreign tourists are distributed to other areas which do not possess direct flight from their respective country of origin. Bali itself has built an international airport ready to accommodate international airlines to directly land forgoing transit.

The frequency of international flights to Jakarta is very high that makes foreign tourists in Jakarta also high. Travel agents also argue that the high number of foreign tourists in DKI Jakarta is not necessarily tourists visiting DKI Jakarta, because when they arrived in DKI Jakarta, they will be listed as tourists of DKI Jakarta, but they can only transit and continue to other cities in Indonesia but recorded in airport immigration is as a foreign tourist of DKI Jakarta. This is caused by foreign tourists requirement to transit in DKI Jakarta.

The condition of tourism in DKI Jakarta which ranks 2 nd in the number of foreign tourist arrivals to Indonesia. DKI Jakarta, which ranks 2 nd in the number of foreign tourist arrivals argue that in this case there are many factors in which one of the factors of infrastructure availability that affect the arrival of foreign tourists to DKI Jakarta. The government and the private sector argued about the visit of foreign tourists to DKI Jakarta is a MICE tour (Meeting, Incentive, Convention, and Exhibition). It is recognized by the government and 
private parties who play a role in the distribution channels of foreign tourists to DKI Jakarta because the infrastructure in Jakarta is adequate for the needs of conventions such as the Jakarta Convention Center, Senayan Convention Hall and so forth. It is inversely related to tourism in Bali which tourism products are nature tourism because DKI Jakarta is a rapidly developing megapolitan city regarding infrastructure development.

Types of Tourists. The types of tourists visiting DKI Jakarta varies. The private sector argues that the high number of foreign tourist arrivals in Jakarta does not determine that their final destination is DKI Jakarta. Foreign tourists transit at the airport before proceeding to another area. As IUOTO (International Union of Official Travel Organization) stated in Pitana et al (2005: 43), foreign tourists are included in the category of travelers/visitors (excursionist), i.e those who live in tourist destinations less than 24 hours, because they only transit in DKI Jakarta before continuing their journey to other areas in Indonesia.

The private sector also argues that foreign tourists are not using their services to travel in Jakarta, in addition, there is lack of city tour for foreign tourists. Foreign tourists merely purchase airplane tickets, hotel reservations or transportation purposes, but for their own travel arrangements. According to Cohen (1972, in Pitana et al, 2005: 53-54) clarified Explorer as tourists who travel by arranging their own journey, and seeking uncommon matter (off the beaten track). Tourists, such are these are willing to take advantage of facilities with local standards and interact with locals.

The condition is also supported by the statements of foreign tourists who have been interviewed researchers, Vojtech Bazant and Kieran Rieley. They acknowledge that they do not use the services of private parties during their visits to DKI Jakarta. They merely their own air ticket to DKI Jakarta and seek the nearest hotel without telling their travel arrangements to travel agents.

Types of Distribution Channel. According to Tan (2010: 142), there are 3 categories tourism distribution channels: Tour Operator, Broker, and Travel Agent. Indo Citra Tamasya as a private company engaged in tourism is included in the category of Tour Operator. Indo Citra Tamasya provides outbound tour packages (abroad) known as holiday package. Related to the distribution channel of foreign tourists in DKI Jakarta, ICT (Indo Citra Tamasya) do not provide tour packages for DKI Jakarta. Even after 8 years of company history, ICT does not provide tour packages for DKI Jakarta region.

DKI Jakarta as a metropolitan city makes it an extremely bustling city. DKI Jakarta as the capital city of Indonesia has crowded population. The rapid development of infrastructure makes DKI Jakarta disturbed because of the density and congestion that makes mobility inhibited. ICT also states although many foreign tourists arriving at DKI Jakarta, they do not require city tour or guide. Foreign tourists can book direct flights to DKI Jakarta, hotel reservations, and transportation without the help of travel agents.

\section{CONCLUSION AND SUGGESTIONS}

Based on research result of Distribution Channel Analysis of Foreign Tourist in Indonesia ( A study on DKI Jakarta), the researchers concluded:

The condition of tourism in DKI Jakarta which ranks 2 nd in the number of foreign tourists arrival is described as follows:

a) The gap of foreign tourists in Indonesia is influenced by the readiness of the region and the airport respectively. DKI Jakarta possesses infrastructure, especially in accommodating international airlines for direct flights to DKI Jakarta.

b) Foreign tourists arriving in DKI Jakarta outline possess 3 motives: MICE tourism (Meeting, Incentive, Convention, and Event) due to many multinational companies that set up its branch in Jakarta, therefore, a huge number of foreigners visit Indonesia for corporate meetings. The second purpose is shopping, and lastly is to transiting in DKI Jakarta before continuing the trip to other areas in Indonesia (tourists excursionist / stop under 24h).

c) In general, access to Indonesia is still dominated by DKI Jakarta, due to the readiness of DKI Jakarta airport, the cooperation of international airlines that provide direct 
flights from abroad to DKI Jakarta, it is influential in the distribution channels of foreign tourists in DKI Jakarta.

Based on research result and discussion, there are suggestions that can be used for the parties concerned. The suggestion is intended to provide benefits to the parties concerned. The suggestions are described as follows:

1. The government and private parties ought to work together to facilitate a short city tour in DKI Jakarta, especially for foreign tourists who are in transit. It is to provide tours to tourist waiting for transit in airports, foreign tourists can spend their money to buy consumption, or souvenirs in Jakarta before resuming their flight to other areas

2. Maximizing the infrastructure and access to tourist attractions or museums in DKI Jakarta to attract foreign tourists to visit.

3. International promotion could be provided via the internet, by showing history and culture. Exhibiting unique selling points that can be offered to foreign tourists to visit Indonesia. In general, foreign tourists generally visit a place based on history, culture, and business factors. Should DKI Jakarta succeeds in creating businesses, it will create jobs vacancies and attract foreign tourists to come and build the tourism industry to flourish.

\section{REFERENCES}

1. Fandeli, C. 2001. Dasar-Dasar Manajemen Kepariwisataan Alam. Yogyakarta: Liberty.

2. Foster, D.L. 2000. Fisrt Class An Introduction To Travel and Tourism. Jakarta: Raja Grafindo Persada.

3. Khuong, M.N. \& Ha, H.T.T. 2014. The Influences of Push and Pull Factors on The International Leisure Tourists' Return Intention to Ho Chi Minh City, Vietnam - A Meditation Analysis of Destination Satisfaction. International Journal of Trade, Economics, and Finance, 5(6). 490 - 496.

4. Pendit, N.S. 2006. Ilmu Pariwisata Sebuah Pengantar Perdana. Jakarta: PT Pradnya Paramita.

5. Pitana, I.G. \& Gayatri, P.G. 2005. Sosiologi Pariwisata: Kajian Sosiologis terhadapStruktur, Sistem dan Dampak-Dampak Pariwisata.Yogyakarta: Andi.

6. Sugiyono. 2015. Metode Penelitian Kuantitatif dan Kualitatif dan R\&D. Bandung: Alfabeta.

7. Suwantoro, G. 2004. Dasar-DasarPariwisata. Yogyakarta: Andi.

8. Tan, R.B.P. 2010. Kunci Sukses Memasarkan Jasa Pariwisata. Jakarta: Erlangga.

9. Wardiyanta. 2006. Metode Penelitian Pariwisata. Yogyakarta: Andi.

10. Yiamjanya, S. \& Wongleedee, K. 2014. International Tourists' Travel Motivation by PushPull: Factors and the Decision Making for Selecting Thailand as Destination Choice. World Academy of Science, Engineering, and Technology: International Journal of Social, Behavioral, Educational, Economic, Business and Industrial Engineering, 8(5).1348 1353.

11. Yoeti, O.A. 2002. Perencanaan Strategis Pemasaran Daerah Tujuan Wisata. Jakarta: Pradnya Paramita.

12. Yoeti, O.A. 2003. Tours and Travel Marketing. Jakarta: Pradnya Paramita.

13. Yoeti, O.A. 2008. Ekonomi Pariwisata: Introduksi, Informasi dan Aplikasi. Jakarta: Kompas.

14. Yoeti, O.A. 2013. Pemasaran Pariwisata. Bandung: Angkasa.

(C) 2017 by the author. Licensee RJOAS, Orel, Russia. This article is an open access article distributed under the terms and conditions of the Creative Commons Attribution (CC BY) license: http://creativecommons.org/licenses/by/4.0/ 